\title{
Wspomnienie o Profesor Marii Dąbskiej
}

Prof. dr hab. med. Maria Dąbska była lekarzem specjalistą patomorfologiem onkologiem. Jej pasją życiową była diagnostyka nowotworów. Pracowała w Zakładzie Patologii Nowotworów w Instytucie Onkologii w Warszawie, w którym zdobyła wiedzę $w$ dziedzinie histopatologii onkologicznej. Jej Mentorem był prof. Józef Laskowski. Pod Jego kierunkiem nauczyła się diagnozować nowotwory oraz łączyć obraz mikroskopowy z obrazem klinicznym.

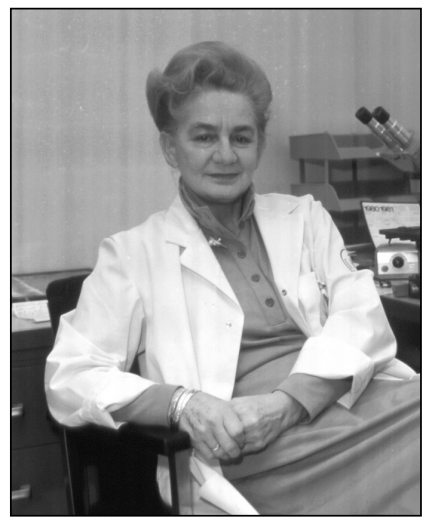

w owych czasach był nowoczesnym kierunkiem postępowania terapeutycznego rozwiniętym w Instytucie Onkologii. Jedną z form konsultacji kliniczno-patologicznych były kominki odbywające się dwa razy w tygodniu, na których zbierali się wszyscy lekarze. Każdy przypadek był referowany i komentowany przez prof. Marię Dąbską lub pozostałych pracowników Zakładu Patologii Nowotworów. Ta forma konsultacji i wzajemnej edukacji była kontynuowana Rozwijała nową dziedzinę w patomorfologii, wprowadzoną przez prof. Józefa Laskowskiego, zwaną histokliniką, która była zwiastunem późniejszego światowego kierunku w patologii, zwanego patologią kliniczną (surgical pathology).

Prof. M. Dąbska, pracując w Instytucie Onkologii, przeszła drogę rozwoju naukowego, zdobywając kolejno tytuły i stopnie naukowe: adiunkta, docenta i profesora. Prof. Tadeusz Koszarowski, doceniając Jej wiedzę oraz umiejętności organizacyjne, powołał Ją na stanowisko kierownika Zakładu Patologii. Pani Profesor kierowała Zakładem Patologii Nowotworów w latach 1970-1982. Dzięki Jej dużemu osobistemu zaangażowaniu Zakład Patologii Nowotworów Instytutu Onkologii w Warszawie przy ul. Wawelskiej stał się ośrodkiem referencyjnym i edukacyjnym w dziedzinie histopatologii onkologicznej dla lekarzy patomorfologów i onkologów w Polsce. Organizowane pod Jej kierunkiem kursy dla patomorfologów prezentowały wysoki poziom naukowy. Uczestniczący w nich lekarze mieli okazję zdobyć praktyczną i aktualną wiedzę onkologiczną. Prof. M. Dąbska, mimo iż większość czasu spędzała przy mikroskopie, była zawsze blisko pacjentów. Na bieżąco kontaktowała się z onkologami, poznając dane kliniczne, obraz endoskopowy czy radiologiczny lub inne istotne informacje na temat przebiegu procesu chorobowego poszczególnych przypadków. Za każdym preparatem mikroskopowym widziała pacjenta, który oczekiwał na Jej diagnozę, decydującą o wyborze metody leczenia. Prof. M. Dąbska była członkiem interdyscyplinarnego zespołu diagnostyczno-leczniczego, który w kolejnych latach pod bacznym okiem prof. Andrzeja Kułakowskiego. Prof. Maria Dąbska miała duży udział w rozwoju cytologii w diagnostyce nowotworów i wprowadzaniu tej metody w Instytucie Onkologii w Warszawie.

Przez wszystkie lata pracy w Instytucie Onkologii w Warszawie Pani Profesor dała się poznać jako mądra, inteligenta i elegancka kobieta, która w swoim postępowaniu wykazywała wiele taktu i rozwagi, rozwiązując problemy merytoryczne, naukowe, jak i organizacyjne.

Prof. Maria Dąbska urodziła się 20 lipca 1921 roku w Brodnicy, zmarła 20 lipca 2014 roku; żyła 93 lata. W czasie II wojny światowej brała udział w podziemnym ruchu niepodległościowym w Warszawie. Walczyła w Powstaniu Warszawskim jako członek Armii Krajowej. Po wojnie studiowała na Akademii Medycznej w Gdańsku. Wiedzę z zakresu patomorfologii zdobywała najpierw w Gdańsku, pod kierunkiem prof. Wilhelma Czarnockiego, a następnie w Instytucie Onkologii w Warszawie. W 1957 r. odbyła półroczny staż na Uniwersytecie w Leeds, u wybitnego onkopatologa prof. Ruperta Alana Willisa. W latach późniejszych, jako doświadczony patomorfolog onkolog, była przyjmowana z najwyższymi honorami na uniwersytetach medycznych w Londynie, Sztokholmie, Bonn, Rochester i Stanford. W latach 80.z powodu wprowadzenia stanu wojennego zdecydowała się na emigrację: najpierw była w Niemczech, potem w USA. W wieku 85 lat przeprowadziła się z Florydy do Warszawy [1]. Do końca zainteresowana była zmianami, jakie zachodziły w obu związanych ze sobą obszarach medycznych, jakimi są patomorfologia i onkologia. 
Osiągnięcia zawodowe prof. Marii Dąbskiej wiązały się z okresem rozwoju Zakładu Patologii Nowotworów Instytutu Onkologii w Warszawie w latach 60-80. Pani Profesor rozpoznawała nowotwory, poznawała ich histogenezę oraz dokonywała pionierskich opisów w literaturze światowej. W 1969 r. opublikowała pracę w międzynarodowym czasopiśmie Cancer [2] i monografię w Polskiej Akademii Nauk, poświęconą badaniom nad zebranymi w Instytucie Onkologii w Warszawie przy ul. Wawelskiej 15 przypadkami wcześniej nierozpoznanego i błędnie zdiagnozowanego nowotworu. Został on nazwany „guzem Dąbskiej". Guz Dąbskiej to bardzo rzadki nowotwór tkanek miękkich, występujący głównie u dzieci, na kończynach lub w obrębie głowy, szyi, jąder lub w innych lokalizacjach, w formie skórnej lub rozlanej. Nowotwór ten zazwyczaj nie jest złośliwy, leczenie polega na resekcji chirurgicznej. Mimo wprowadzonej nazwy anglojęzycznej malignantendovascular papillary angioendothelioma do dnia dzisiejszego znany jest jako „The Dabska Tumor" [3].

Kolejny pionierski opis patokliniczny i radiologiczny dotyczył torbieli aneuryzmatycznej kości. Zawarty on został w publikacji prof. Marii Dąbskiej i prof. Janusza Buraczewskiego w 1969 roku [4]. Następnie w 1977 roku prof. Maria Dąbska, na podstawie opisu 10 przypadków, ostatecznie wprowadziła termin parachordoma [5] (pierwszego opisu tego guza chordoma periphericum dokonał Laskowski w 1951 roku). Równie istotnym wkładem do polskiej onkologii były charakterystyki zmian skórnych, szczególnie wywodzących się z przydatków, jak keratoacanthoma [6], ecrine spiradenoma i raka podstawnokomórkowego. Tematem kolejnego opracowania była zmiana melanocytarna typu znamienia Spitza. Prof. Maria Dąbska w 1956 roku scharakteryzowała tę zmianę na 23 przypadkach (pierwsza publikacja S. Spitza powstała w 1948 roku na 13 przypadkach w Am J Path), opisując szczegółowo warianty komórkowe tego znamienia [7]. Kolejne osiągnięcia prof. Marii Dąbskiej dotyczyły mięsaków tkanek miękkich i kości. Nowotwór określony terminem aponeurotic sarcoma został opisany w polskich czasopismach, najpierw zdefiniowany przez Laskowskiego w 1961 roku [8], a następnie przez Dąbską w 1973 roku [9]. Mięsaka tego równocześnie opisał Enzinger w 1970 roku pod nazwą mięsaka epitelioidnego. Kolejne badania naukowe wynikające z pracy patomorfologa diagnosty dotyczyły nowotworów kości [10-13]. Zawierały one opisy patomorfologiczne tych nowotworów wraz z badaniami ultrastruktury w mikroskopie elektronowym.

Prof. Maria Dąbska brała czynny udział w organizowaniu Polskiego Towarzystwa Patologów i do końca zainteresowana była jego działalnością. W znaczący sposób przyczyniła się do rozwoju patomorfologii onkologicznej i określenia miejsca patomorfologa w onkologii. Jest Ona najbardziej doświadczoną i uznaną na świecie spośród polskich patomorfologów, uhonorowaną eponimem medycznym [14].

Prof. Maria Dąbska była Członkiem Honorowym Polskiego Towarzystwa Patologów i Członkiem Honorowym Oddziału Warszawskiego Polskiego Towarzystwa Onkologicznego.

Z okazji Święta Niepodległości 11 listopada 2012 roku Prezydent Rzeczypospolitej Polskiej Bronisław Komorowski odznaczył Profesor Marię Dąbską Krzyżem Komandorskim Orderu Odrodzenia Polski za wybitne osiągnięcia w pracy naukowo-badawczej i działalności dydaktycznej, za zasługi na rzecz rozwoju nauk medycznych w Polsce i na świecie oraz budowanie fundamentów polskiej onkologii.

Niestety, nie miałam możliwości współpracy z prof. Marią Dąbską. W 1982 roku, gdy ja rozpoczęłam pracę w Zakładzie Patologii Nowotworów Instytutu Onkologii w Warszawie, Pani Profesor już odeszła z Instytutu Onkologii. Szacunek dla Pani Profesor i pamięć o Niej pozostanie wśród nas.

\section{Prof. Anna Nasierowska-Guttmejer}

Prezes Polskiego Towarzystwa Patologów

Zakład Patomorfologii Centralnego Szpitala Klinicznego MSW

w Warszawie

e-mail:anna.guttmejer@gmail.com

\section{Piśmiennictwo}

1. Historia. Strona internetowa Wspólnoty Mieszkaniowej przy ul. Marszałkowskiej 68/70 w Warszawie. www.marszalkowska.eu. [dostęp 2012-05-14].

2. Dabska M. Malignant endovascular papillary angioendothelioma of the skin in childhood. Clinicopathological study of 6 cases. Cancer 1969; 24: 503-510.

3. Schwartz RA, Dabski C, Dabska M. The Dabska tumor: a thirty-year retrospect. Dermatology 2000; 201: 1-5.

4. Dabska M, Buraczewski J. Aneurysmal bone cyst. Pathology, clinical course and radiologic appearances. Cancer 1969; 23: 371-389.

5. Dabska M. Parachordoma: a new clinicopathologic entity. Cancer 1977; 40: 1586-1592.

6. Dabska M. Keratoacanthoma. Wiad Lek 1965; 18: 1249-1250.

7. Dabska M. Melanoma juvenile. Nowotwory 1956; 6: 103-112.

8. Laskowski J. Aponeurotic sarcoma. Pol Med J 1971; 10: 1-11.

9. Dabska M, Meyza J, Nowacki M. Sarcoma aponeuroticum (sarkoma of the aponeurosis). Pol Tyg Lek 1973; 28: 99-102.

10. Dabska M, Huvos AG. Mesenchymal chondrosarcoma of the young Virchows Arch A Pathol Anat Histopathol 1983; 399: 89-104.

11. Sieiński W, Dabska M. Osteogenic sarkoma according to the materials of the Department of Pathology of the Warsaw Oncological Institute for the years 1948-1977. Nowotwory 1979; Suppl: 47-52.

12. Dabska M. Osteogenic sarcoma and its morphological "masks". Nowot wory. 1979; Suppl: 35-46.

13. Pietrow D, Jeziorska M, Dabska M. The usefulness of electron microscopy in the diagnosis of some selected cases of soft tissue tumors. Acta Med Pol 1979; 20: 449-450.

14. Schwartz RA, Janniger EJ.: On being a pathologist: Maria Dąbska — the woman behind the eponym, a pioneer in pathology. Hum Pathol 2011; 42: 913-917. 